\title{
Uptake of Gallium-67 by the Hepatocytes during Liver Regeneration in Carbon Tetrachloride-Treated Mice
}

\author{
Shinya Abe,* Satoko Suyama, Hitomi Shishido, Masayoshi Sato, Yosuke Ohtake, Naoko Sato, and \\ Yasuhito OHKUво \\ Department of Radiopharmacy, Tohoku Pharmaceutical University; 4-4-1 Komatsushima, Aoba-ku, Sendai, Miyagi \\ 981-8558, Japan. Received July 14, 2004; accepted August 21, 2004
}

Gallium-67 $\left({ }^{67} \mathrm{Ga}\right)$ has been used as a tumor or inflammation-imaging agent in nuclear medicine. We recently reported that the peak of serum alanine aminotransferase (ALT) level was $1 \mathrm{~d}$ after carbon tetrachloride $\left(\mathrm{CCl}_{4}\right)$ treatment in rats. However, the peak of ${ }^{67} \mathrm{Ga}$ uptake by the liver tissue and hepatocytes was $2 \mathrm{~d}$ after the treatment. If ${ }^{67} \mathrm{Ga}$ is taken in the hepatic disorder phase, the pattern of ${ }^{67} \mathrm{Ga}$ uptake by the hepatocytes should be consistent with that of the ALT level. In order to answer why it was not, we carried out a detailed examination. The lipid peroxidation of hepatocytes from $\mathrm{CCl}_{4}$-treated mice was greatly increased $1 \mathrm{~d}$ after $\mathbf{C C l}_{4}$ treatment; serum ALT was also increased $1 \mathrm{~d}$ after the treatment. The uptake of ${ }^{67} \mathrm{Ga}$ by the liver tissue reached a maximum 1 and $2 \mathrm{~d}$ after the treatment, while maximum by the hepatocytes was achieved after $2 \mathrm{~d}$. The incorporation of bromodeoxyuridine into the hepatocytes also reached maximum $2 \mathrm{~d}$ after the treatment. These results suggest that the uptake of ${ }^{67} \mathrm{Ga}$ by the hepatocytes is carried out during liver regeneration rather than during hepatic disorder by $\mathrm{CCl}_{4}$ treatment. $(\operatorname{BrdU})$

Key words Gallium-67 ( $\left.{ }^{67} \mathrm{Ga}\right)$; carbon tetrachloride $\left(\mathrm{CCl}_{4}\right)$; liver tissue; hepatocyte; lipid peroxidation; bromodeoxyuridine

Gallium-67 ( $\left.{ }^{67} \mathrm{Ga}\right)$ has been used for the detection of various tumors ${ }^{1,2)}$ and acute and chronic inflammations, ${ }^{3,4)}$ since the first observation of its accumulation in tumors ${ }^{5)}$ and inflammatory lesions. ${ }^{6,7)}$ Moreover, in chronic hepatitis $\mathrm{C}$, it was reported that there was more accumulation in the liver in patients with chronic persistent hepatitis than in those with cirrhosis. ${ }^{8)}$ Although many hypotheses concerning the mechanism of ${ }^{67} \mathrm{Ga}$ uptake by tumors and inflammatory lesions have been proposed, consensus has not been reached.

We recently reported that serum ALT level of carbon tetrachloride $\left(\mathrm{CCl}_{4}\right)$ treated rats reached a maximum within $1 \mathrm{~d}$, whereas maximum uptake of ${ }^{67} \mathrm{Ga}$ by the liver tissue and hepatocytes was reached in $\left.2 \mathrm{~d} .^{9}\right)$ Most hepatotoxic effects of $\mathrm{CCl}_{4}$ are attributed to its metabolism by cytochrome $\mathrm{P} 450$, especially by $\mathrm{P} 4502 \mathrm{E} 1$, to yield toxic trichloromethyl radical $\left(\mathrm{CCl}_{3}{ }^{*}\right){ }^{10)}$ This radical can react with oxygen to form the trichloromethylperoxy radical $\left(\mathrm{CCl}_{3} \mathrm{OO} *\right)$, a highly reactive species. ${ }^{11)}$ The radical initiates the chain reaction of lipid peroxidation. ${ }^{12,13)}$ This affects the permeabilities of mitochondrial, endoplasmic reticulum, and plasma membranes, resulting in the loss of cellular calcium sequestration and homeostasis; this, in turn, can contribute heavily to subsequent cell damage. ${ }^{14-16)}$

If ${ }^{67} \mathrm{Ga}$ is taken in the hepatic disorder phase, the pattern of uptake by the hepatocytes should be consistent with that of lipid peroxidation. A detailed examination was carried out to learn why this was apparently not so.

\section{MATERIALS AND METHODS}

Animals Male $d d \mathrm{Y}$ mice weighing 24-34 g (SLC, Hamamatsu, Japan) were kept under conditions of a $12 \mathrm{~h}$ light-dark cycle, $23 \pm 1{ }^{\circ} \mathrm{C}$ and $55 \pm 5 \%$ humidity, and had free access to food and water. Animals were cared following the standard procedures indicated in the "Guide for the Care and Use of Laboratory Animals" published by the Tohoku
Pharmaceutical University.

Administration of $\mathbf{C C l}_{4}$ Mice were given a $10 \%$ suspension of $\mathrm{CCl}_{4}$ in olive oil $(10 \mathrm{ml} / \mathrm{kg})$ orally, after being fasted for $16 \mathrm{~h}$.

Determination of Serum Alanine Aminotransferase (ALT) Activity Serum alanine aminotransferase (L-alanine-oxoglutarate aminotransferase, EC 2.6.1.2) (ALT) activity was determined by the method of Reitman and Frankel, ${ }^{17}$ ) and expressed as Karmen units (KU) per ml of serum.

Administration of ${ }^{67} \mathbf{G a}$ Gallium-67 citrate (Daiichi Radioisotope Laboratory, Ltd., Tokyo, Japan) was diluted with saline to $74 \mathrm{kBq} / \mathrm{ml}$. Each mouse was injected subcutaneously with ${ }^{67} \mathrm{Ga}$ at a dose of $7.4 \mathrm{kBq}(100 \mu \mathrm{l})$.

Removal of Liver The mice were administered ${ }^{67} \mathrm{Ga}$ under urethane anesthetization $(1.5 \mathrm{~g} / \mathrm{kg}$, i.p.). After $4 \mathrm{~h}$ they were immediately perfused with $0.9 \% \mathrm{NaCl}$ solution. The whole liver was then removed. The amount of radioactive ${ }^{67} \mathrm{Ga}$ was determined with a well-type NaI-scintillation counter (ARC-300, Aloka, Japan). The uptake ratio of ${ }^{67} \mathrm{Ga}$ in the liver was expressed using the following formula:

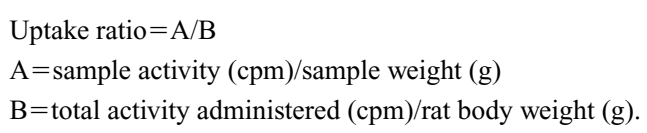

Preparation of Hepatocytes Hepatocytes were isolated from mice as described previously ${ }^{18)}$ : briefly, hepatocytes were isolated by a method in which the liver was perfused with collagenase (Nitta Gelatin, Osaka, Japan). The hepatocytes were counted with a well-type NaI-scintillation counter and the results expressed as cpm/ $1 \times 10^{6}$ cells.

Determination of Hepatic Lipid Peroxidation The extent of lipid peroxidation was estimated in hepatocyte homogenates by determining malondialdehyde (MDA) formation using the thiobarbituric acid method. ${ }^{19)}$ Hepatocyte samples were homogenized with $1.15 \% \mathrm{KCl}$. A fraction from the homogenate was combined with thiobarbituric reagent $[15 \%$ 
$(\mathrm{w} / \mathrm{v})$ trichloroacetic acid, $0.375 \%(\mathrm{w} / \mathrm{v})$ thiobarbituric acid dissolved in $0.25 \mathrm{M}$ of hydrochloric acid], the mixture was heated for $15 \mathrm{~min}$ in a boiling water bath. After cooling, the precipitate was removed by centrifugation at $2000 \times \boldsymbol{g}$ for $10 \mathrm{~min}$. Following decanting of the supernatant, the absorbance was determined at $535 \mathrm{~nm}$ against a blank that contained all the reagents minus sample. The MDA concentration from the samples was calculated using an extinction coefficient of $1.56 \times 10^{5} \mathrm{M}^{-1} \mathrm{~cm}^{-1}$. The results were expressed as the concentration of MDA/mg protein.

Flow Cytometric Analysis of Cell Cycle Cell cycle was analyzed using a BrdU Flow Kit (Becton Dickinson, San Diego, CA, U.S.A.). BrdU was dissolved in phosphate buffered saline (PBS) and was given intravenously $(10 \mathrm{mg} / \mathrm{kg}) 2 \mathrm{~h}$ before killing. Incorporation of BrdU into hepatocytes was detected by FACScan (Becton Dickinson).

\section{RESULTS}

Changes in the Lipid Peroxidation of Hepatocytes from $\mathbf{C C l}_{4}$-Treated Mice To ascertain the degree of disorder in the hepatocytes, we determined the lipid peroxidation by thiobarbituric acid assay (Fig. 1). The peroxidation increased after $\mathrm{CCl}_{4}$ treatment and showed the highest value (7.2 times higher than that of normal mice) $1 \mathrm{~d}$ after the treatment.

Changes in Serum ALT Level after $\mathrm{CCl}_{4}$ Treatment Serum ALT level also increased after $\mathrm{CCl}_{4}$ treatment and reached a maximum in $1 \mathrm{~d}$ (Fig. 2). Two days after the treatment the value rapidly decreased.

Uptake of ${ }^{67} \mathbf{G a}$ by Liver and Hepatocytes after $\mathbf{C C l}_{4}$ Treatment The uptake of ${ }^{67} \mathrm{Ga}$ by the liver tissue increased 1 and $2 \mathrm{~d}$ after $\mathrm{CCl}_{4}$ treatment (Fig. 3), while the uptake of ${ }^{67} \mathrm{Ga}$ by the hepatocytes showed the highest value ( 8.5 times higher than that of normal mice) $2 \mathrm{~d}$ after treatment (Fig. 4).

Changes in the Incorporation of Bromodeoxyuridine into Hepatocytes after $\mathbf{C C l}_{4}$ Treatment To confirm DNA synthesis of hepatocytes during liver regeneration after $\mathrm{CCl}_{4}$ induced hepatic disorder, we determined their incorporation of BrdU (Fig. 5). Incorporation reached a maximum $2 \mathrm{~d}$ after $\mathrm{CCl}_{4}$ treatment.

\section{DISCUSSION}

We recently reported that serum ALT level of $\mathrm{CCl}_{4}$-treated rat reached a maximum $1 \mathrm{~d}$ after the treatment, whereas the uptake of ${ }^{67} \mathrm{Ga}$ by the liver tissue and hepatocytes was highest $2 \mathrm{~d}$ after treatment. ${ }^{9)}$

In the present study, we confirmed the precise index of disordered hepatocytes by the degree of lipid peroxidation (Fig. 1). The lipid peroxidation of hepatocytes from $\mathrm{CCl}_{4}$-treated mice was greatly increased within $1 \mathrm{~d}$ of the treatment. Furthermore, serum ALT (a conventional indicator of hepatic disorder) was also increased within $1 \mathrm{~d}$ (Fig. 2). This result was consistent with that of $\mathrm{CCl}_{4}$-treated rats, ${ }^{9)}$ and indicated that hepatocyte destruction occurred within $1 \mathrm{~d}$ after $\mathrm{CCl}_{4}$ treatment.

The uptake of ${ }^{67} \mathrm{Ga}$ by the liver tissue increased 1 and $2 \mathrm{~d}$ after the treatment (Fig. 3). However, uptake by the hepatocytes reached a maximum after $2 \mathrm{~d}$ (Fig. 4). Moreover, little ${ }^{67} \mathrm{Ga}$ was present in the nonparenchymal cells (data not shown). Therefore, we theorized that a large amount of ${ }^{67} \mathrm{Ga}$

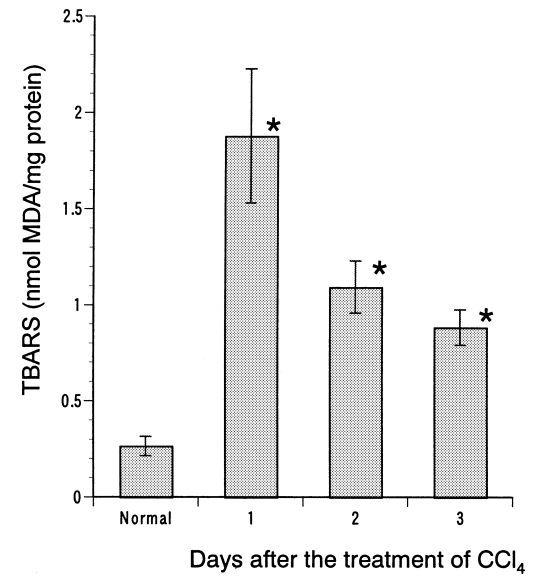

Fig. 1. Time Course of the Thiobarbituric Acid-Reactive Substances (TBARS) Production in Whole Homogenates of Hepatocytes after the Treatment of Carbon Tetrachloride $\left(\mathrm{CCl}_{4}\right)$

Each point represents the mean \pm S.E. of $4-5$ mice. The data were analyzed by Student's $t$-test. $* p<0.01$ compared with normal mice.

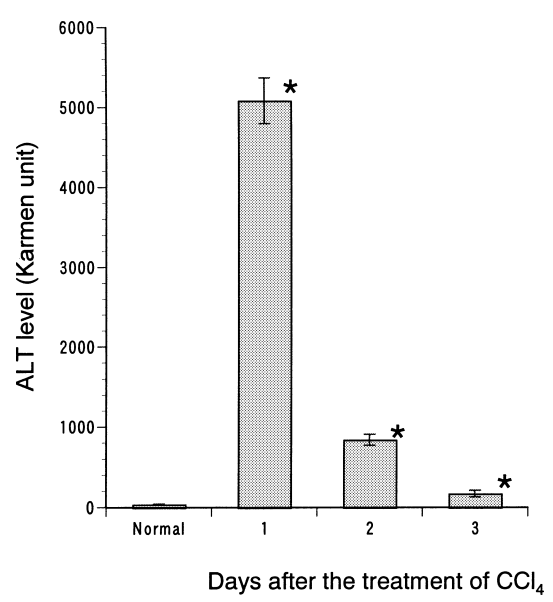

Fig. 2. Time Course of Serum Alanine Aminotransferase (L-Alanine-Oxoglutarate Aminotransferase, EC 2.6.1.2) Levels after the Treatment of Carbon Tetrachloride $\left(\mathrm{CCl}_{4}\right)$

Each point represents the mean \pm S.E. of $4-5$ mice. The data were analyzed by Student's $t$-test. $* p<0.01$ compared with normal mice.

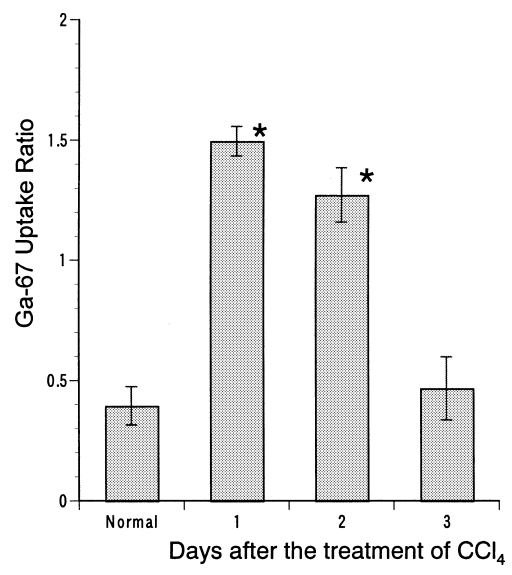

Fig. 3. Time Course of the Uptake Ratio of ${ }^{67} \mathrm{Ga}$ by the Liver Tissue after the Treatment of Carbon Tetrachloride $\left(\mathrm{CCl}_{4}\right)$

Each point represents the mean \pm S.E. of $4-5$ mice. The data were analyzed by Student's $t$-test. $* p<0.01$ compared with normal mice. 


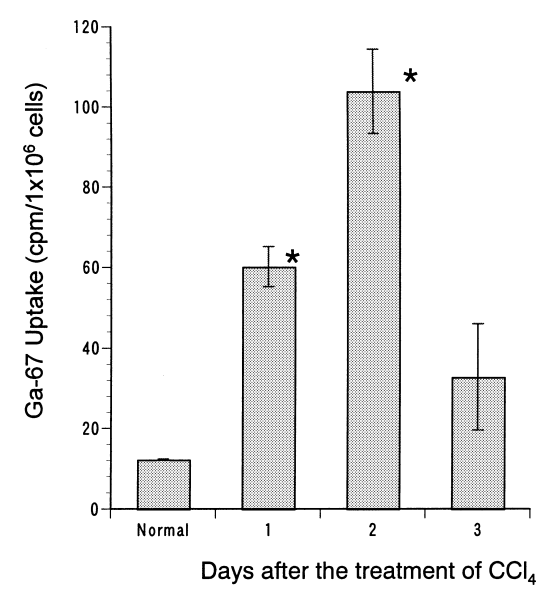

Fig. 4. Time Course of the Uptake of ${ }^{67} \mathrm{Ga}$ by the Hepatocytes after the Treatment of Carbon Tetrachloride $\left(\mathrm{CCl}_{4}\right)$

Each point represents the mean \pm S.E. of $4-5$ mice. The data were analyzed by Student's $t$-test. $* p<0.01$ compared with normal mice.

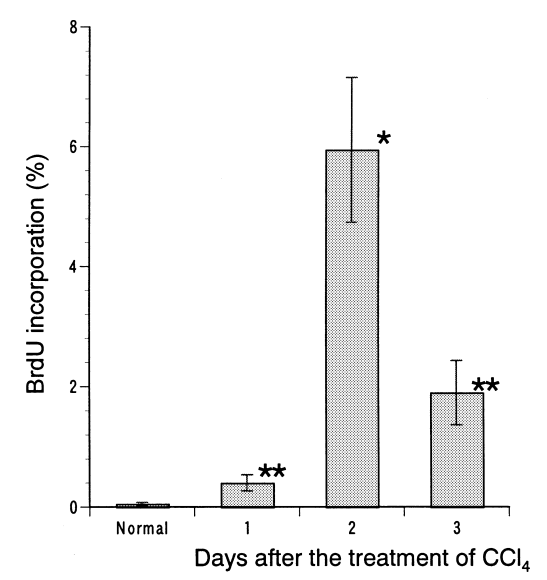

Fig. 5. Time Course of the Incorporation of Bromodeoxyuridine into Hepatocytes after the Treatment of Carbon Tetrachloride $\left(\mathrm{CCl}_{4}\right)$

Each point represents the mean \pm S.E. of $4-5$ mice. The data were analyzed by Student's $t$-test. $* p<0.01$ and $* * p<0.05$ compared with normal mice.

taken by liver tissue may already exist extracellular matrix. This speculation is supported by the report that ${ }^{67} \mathrm{Ga}$ bound to heparan sulfate ${ }^{20)}$ and that $\mathrm{CCl}_{4}$ treatment caused an increase of this substance in rat. ${ }^{21-23)}$

The pattern of ${ }^{67} \mathrm{Ga}$ uptake by the hepatocytes was not consistent with the peak of serum ALT and lipid peroxidation, suggesting that the uptake was not carried out during hepatic disorder. Therefore, we suspected that ${ }^{67} \mathrm{Ga}$ uptake by hepatocytes might correlate with hepatocyte proliferation during liver regeneration after hepatic disorder caused by
$\mathrm{CCl}_{4}$ treatment.

To ascertain the relationship between ${ }^{67} \mathrm{Ga}$ uptake and cell proliferation, we confirmed DNA synthesis of the regenerating hepatocytes after the $\mathrm{CCl}_{4}$ treatment. The incorporation of BrdU into the hepatocytes reached a maximum $2 \mathrm{~d}$ after the treatment (Fig. 5). This pattern of hepatic DNA synthesis was consistent with that of ${ }^{67} \mathrm{Ga}$ uptake by the hepatocytes.

In conclusion, our data demonstrated that the uptake of ${ }^{67} \mathrm{Ga}$ by the hepatocyte is carried out during hepatocytes proliferation rather than hepatic disorder following $\mathrm{CCl}_{4}$ treatment.

\section{REFERENCES}

1) Bekerman C., Hoffer P. B., Bitran J. D., Semin. Nucl. Med., 14, 296323 (1984).

2) Halpern S. H. P., "Gallium-67 Citrate Imaging in Neoplastic and Inflammatory Disease,” Raven Press, New York, 1980.

3) Hoffer P., J. Nucl. Med., 21, 484-488 (1980).

4) Lin W. Y., Lan J. L., Wang S. J., J. Nucl. Med., 39, 2137-2141 (1998).

5) Edwards C. L., Hayes R. L., J. Nucl. Med., 10, 103-105 (1969).

6) Ito Y. O. S., Sato K., Takahashi K., Sato T., Kanno I., Radiology, 100, 357-362 (1971).

7) Lavender J. P., Lowe J., Barker J. R., Burn J. I., Chaudhri M. A., Br. J. Radiol., 44, 361-366 (1971).

8) Shiomi S., Kuroki T., Yokogawa T., Takeda T., Nishiguchi S., Nakajima S., Tanaka T., Okamura T., Ochi H., J. Nucl. Med., 38, 216-219 (1997).

9) Abe S., Hasegawa S., Nirasawa M., Sato N., Ohkubo Y., Hepatol. Res., 25, 306-311 (2003).

10) Castillo T., Koop D. R., Kamimura S., Triadafilopoulos G., Tsukamoto H., Hepatology, 16, 992-996 (1992).

11) Mico B. A., Pohl L. R., Arch. Biochem. Biophys., 225, 596-609 (1983).

12) Link B., Durk H., Thiel D., Frank H., Biochem. J., 223, 577-586 (1984).

13) Tribble D. L., Aw T. Y., Jones D. P., Hepatology, 7, 377-386 (1987).

14) Haouzi D., Lekehal M., Moreau A., Moulis C., Feldmann G., Robin M. A., Letteron P., Fau D., Pessayre D., Hepatology, 32, 303-311 (2000).

15) Jaeschke H., Smith C. W., Clemens M. G., Ganey P. E., Roth R. A., Toxicol. Appl. Pharmacol., 139, 213-226 (1996).

16) Nicotera P., Bellomo G., Orrenius S., Annu. Rev. Pharmacol. Toxicol., 32, $449-470$ (1992).

17) Reitman S., Frankel S., Am. J. Clin. Pathol., 28, 56-63 (1957).

18) Abe S., Hasegawa S., Nirasawa M., Sasaki M., Ohkubo Y., Biol. Pharm. Bull., 24, 1343-1346 (2001).

19) Buege J. A., Aust S. D., Methods Enzymol, 52, 302-310 (1978).

20) Abe S., Shimizu Y., Ohtsuki J., Ohkubo Y., Biol. Pharm. Bull., 25, 1209-1211 (2002).

21) Szende B., Lapis K., Kovalszky I., Timar F., In Vivo, 6, 355-361 (1992).

22) Kojima S., Hama Y., Sasaki T., Kubodera A., Eur. J. Nucl. Med., 8, $52-59$ (1983).

23) Suzuki S., Nakamura N., Koizumi T., Biochim. Biophys. Acta, 428, 166-181 (1976) 